\title{
Contextual Effect of Integrated Health Post on the Community Health Personnel Performance: A Multilevel Evidence from Purworejo, Central Java
}

\author{
Ulfah Hidayati'1), Didik Gunawan Tamtomo²), Bhisma Murti') \\ 1)Masters Program in Public Health, Universitas Sebelas Maret \\ 2)Faculty in Medicine, Universitas Sebelas Maret
}

\section{ABSTRACT}

Background: Integrated health post (posyan$\mathrm{du}$ ) is an effort to improve the health of the nearest infants in the community. The community health personnel are in charge of managing and carrying out posyandu activities. Community health personnel performance influences the success of the posyandu program. This study aimed to determine posyandu contextual factors on the performance of community health personnel in infant health services.

Subjects and Method: This was a cross sectional study conducted at 25 posyandu in Purworejo Regency, Central Java, in October 2019. The sample consisted of 200 community health personnel selected by simple random sampling. The dependent variable was community health personnel performance. The independent variables were number of children, education, occupation, income, tenure, skills and work environment. The data was collected by questionnaire. The data were analyzed by multilevel multiple logistic regression.

Results: Posyandu community health personnel performance increased with the number of children $<3(b=1.89 ; 95 \% \mathrm{CI}=0.51$ to $3.26 ; \mathrm{p}=$ 0.007), $\geq$ senior high school $(b=1.88 ; 95 \% \mathrm{CI}=$ 0.31 to $3.44 ; \mathrm{p}=0.019$ ), community health per- sonnel worked at home $(\mathrm{b}=2.15 ; 95 \% \mathrm{CI}=0.48$ to $3.82 ; \mathrm{p}=0.011)$, income $\geq R p 1,200,000(b=1.86$; $95 \% \mathrm{CI}=0.19$ to $3.54 ; \mathrm{p}=0.029$ ), tenure $\geq 3$ years $(b=2.29 ; 95 \% \mathrm{CI}=0.71$ to $3.87 ; \mathrm{p}=0.005)$, good skills $(b=2.34 ; 95 \% \mathrm{CI}=0.53$ to $4.16 ; \mathrm{p}=0.011)$, and good working environment $(\mathrm{b}=1.54 ; 95 \%$ $\mathrm{CI}=0.01$ to $3.06 ; \mathrm{p}=0.048$ ). Posyandu had a contextual effect on community health personnel performance with ICC $=34.98 \%$.

Conclusion: Community health personnel performance increases with the number of children $<3$, $\geq$ senior high school, community health personnel working at home, family income $\geq R p$ $1,200,000$, working period $\geq 3$ years, good skills, and good work environment. Posyandu has a contextual effect on community health personnel performance.

Keywords: performance, community health personnel, posyandu, multilevel analysis

\section{Correspondence:}

Ulfah Hidayati. Master Program in Public Health, Universitas Sebelas Maret, Jl. Ir. Sutami 36A, Surakarta, Central Java. Email: ulfahhidayatimg13@gmail.com. Mobile: +6285725932516.

Cite this as:

Hidayati U, Tamtomo DG, Murti B (2020). Contextual Effect of Integrated Health Post on the Community Health Personnel Performance: A Multilevel Evidence from Purworejo, Central Java. J Health Policy Manage. 5(1): 1-12. https://doi.org/10.26911/thejhpm.2020.05.01.01

Journal of Health Policy and Management is licensed under a Creative Commons Attribution-NonCommercial-ShareAlike 4.0 International License.

\section{BACKGROUND}

The Sustainable Development Goals (SDGs) target of child development indicators is to eliminate malnutrition in children and eliminate child deaths from treatable diseases. The efforts of the Indonesian government for children's health include: infants getting immunizations, getting adequate nutrition, getting adequate health services, and others (Ministry of PPPA and BPS, 2018).

Respiratory infections, diarrhea, neurological diseases (including meningitis and 
encephalitis), and typhus are diseases that often attack Indonesian children (Bappenas, 2015). Indonesia is at the $5^{\text {th }}$ place in the Infant Mortality Rate (IMR) in ASEAN. The number of IMR in Indonesia was 32 per 1,000 live births (Ministry of PPPA and BPS, 2018). In 2030, SDGs predicts IMR in Indonesia to be 25 per 1,000 live births (PBB, 2015). The 2017 IMR in Central Java is 9.49 per 1,00o live births. The coverage of infant services in Central Java is $89.21 \%$ and in Purworejo Regency is 69.90\% (Central Java Health Office, 2018).

Infant health services are health services provided to the ages of 059 months. The services consist of: monitoring growth, development and supplementation. Efforts to under-five health services by involving the community are monitoring growth and recovery (Central Java Health Office, 2018).

Posyandu is a form of Community Based Health Efforts (UKBM) (Ministry of Health, 2012). The community is responsible for managing and carrying out activities in the posyandu. Activities at the posyandu include 5 main priority programs, namely: $\mathrm{MCH}$, Family Planning (KB), Nutrition, Immunization, and diarrhea prevention (Ministry of Health, 2019). Posyandu requires community health personnel to manage and organize activities (Khoirunisa et al., 2019). Community health personnel activities in conducting posyandu include data collection of targets, target summons, village level coordination meetings, organizing a 5table posyan$\mathrm{du}$ system, and postguided meetings (Tristanti and Risnawati, 2017; Bidayati, 2017).

Based on a preliminary study conducted at the Purworejo District Health Office, the number of posyandu was 1.554 posyandu. The number of posyandu community health personnel was 8,465 people and active community health personnel were 7,444 or 87.94\% people.
Community health personnel performance is the result of community health personnel achievement in carrying out the duties and obligations of community health personnel (Kuule et al., 2017). Community health personnel performance is influenced by individual, organizational, and psychological factors (Andriani et al., 2016). Criteria for determining performance include work results, targets and targets (Kusumawardani and Muljono, 2018). According to Palazuelos et al. (2016) in Kok et al. (2017), community health personnel with good performance will tend to work responsively, fairly and efficiently in providing services. Increasing community health personnel in low and middle income countries is a complex matter. To improve the performance of community health personnel, we need to review in various matters that affect performance including the ability and willingness of community health personnel to carry out their duties. Community health personnel performance can affect infant health services at posyandu.

Based on the description above, the authors are interested in conducting study with the title "The contextual effect of integrated health post on the performance of community health personnel: A multilevel of evidence from Purworejo, Central Java".

\section{SUBJECTS AND METHOD}

\section{Study Design}

This was an analytic observational method with a cross sectional approach. This study conducted at 25 posyandu in Purworejo, Central Java in October 2019.

\section{Population and Sample}

The target population is all posyandu community health personnel in Purworejo Regency, Central Java. Total of 200 community health personnel were selected by simple random sampling. 


\section{Study Variables}

The dependent variable was community health personnel performance. The independent variables were the number of children, education, employment status, family income, tenure, skills and work environment.

4. Operational Definition of Variables Performance was a perceptive assessment of study subjects on work results or work achievements as community health personnel. The data were measured by questionnaire. The measurement scale was continuous and transformed into dichotomous.

The number of children was the number of children who are dependent on the study subject of the family. The data were measured by questionnaire. The measurement scale was continuous and transformed into dichotomous.

Education was the last education pursued by the subject in accordance with the last diploma owned. The data were measured by questionnaire. The measurement scale was categorical.

Occupation was the occupation that is of the subjects in addition to being posyandu community health personnel. The measuring instrument was a questionnaire. The scale of the data was categorical.

Family income was the average amount of income obtained by the subjects' families in the past 3 months. The data were measured by questionnaire. The measurement scale was continuous and transformed into dichotomous.

Tenure was the length of time the subject becomes a community health personnel of Posyandu infants until the time the study was carried out. The data were measured by questionnaire. The measurement scale was continuous and transformed into dichotomous.

Community health personnel skills were the ability of community health person- nel in providing services competently. The data were measured by questionnaire. The measurement scale was continuous and transformed into dichotomous.

Working environment was a community health personnel's subjective opinion of the environment around posyandu activityes. The data were measured by questionnairere. The measurement scale was continuous and transformed into dichotomous.

\section{Data Analysis}

Univariate analysis is a general description of data on each variable, presented in $n$, percentage, mean, standard deviation (SD), minimum, and maximum. Bivariate analysis shows the relationship of one independent variable to one dependent variable which is performed using the chi square test. Multivariate analysis shows the relationship of more than one independent variable performed by a multilevel multiple logistic regressions. The analysis was performed using Stata 13.

\section{Research Ethic}

The research ethics consists of informed consent, anonymity, confidentiality, ethical eligibility. The examination was conducted by Health Research Ethics Commission of the Dr. Moewardi Regional General Hospital, Surakarta, Central Java, with number: 1.074/IX/HREC/2019.

\section{RESULTS}

\section{Sample Characteristics}

Table 1 shows the characteristics of continuous data. Meanwhile, table 2 shows the characteristics of categorical data. 136 community health personnel (68\%) have children $<3,162(81 \%)$ have education $\geq$ senior high school, 158 (79\%) work at home, have family income $\geq \operatorname{Rp~1,200,000,~} 149$ (74.5\%) have tenure $\geq 3$ years, $152(76 \%)$ have good skills, and 126 (63\%) have a good work environment. 
Hidayati et al./ Contextual Effect of Integrated Health Post on the Community

Table 1. Sample Characteristics (continuous data)

\begin{tabular}{lccccc}
\hline \multicolumn{1}{c}{ Variable } & n & Mean & SD & Min. & Max. \\
\hline Total number of children & 200 & 2.05 & 1.00 & 0 & 6 \\
Family Income (Rp) & 200 & $1,588,500$ & $1,213,686$ & 500,000 & 15, ooo,ooo \\
Tenure (years) & 200 & 8.08 & 7.30 & 1 & 38 \\
Skills & 200 & 49.31 & 2.77 & 40 & 51 \\
Environment & 200 & 31.08 & 2.06 & 26 & 33 \\
\hline
\end{tabular}

Table 2. Characteristics of study subjects (categorical data)

\begin{tabular}{|c|c|c|}
\hline $\begin{array}{l}\text { Variable } \\
\end{array}$ & $\mathbf{n}$ & \% \\
\hline \multicolumn{3}{|l|}{ Total number of children } \\
\hline$\geq 3$ children & 64 & 32 \\
\hline$<3$ children & 136 & 68 \\
\hline \multicolumn{3}{|l|}{ Education } \\
\hline$<$ Senior high school & 38 & 19 \\
\hline zSenior high school & 162 & 81 \\
\hline \multicolumn{3}{|l|}{ Occupation } \\
\hline Working outside of home & 42 & 21 \\
\hline Working at home & 158 & 79 \\
\hline \multicolumn{3}{|l|}{ Family Income } \\
\hline$<$ Rp. 1,200,000 & 47 & 23.5 \\
\hline$\geq$ Rp. $1,200,000$ & 153 & 76.5 \\
\hline \multicolumn{3}{|l|}{ Tenure } \\
\hline$<3$ years & 51 & 25.5 \\
\hline$\geq 3$ years & 149 & 74.5 \\
\hline \multicolumn{3}{|l|}{ Skills } \\
\hline Poor & 48 & 24 \\
\hline Good & 152 & 76 \\
\hline \multicolumn{3}{|l|}{ Working environment } \\
\hline Poor & 74 & 37 \\
\hline Good & 126 & 63 \\
\hline
\end{tabular}

\section{The result of bivariate analysis}

Table 3 shows the influence of community health personnel performance increases with the number of children $<3(\mathrm{OR}=15.53 ; 95 \%$ $\mathrm{CI}=7.48$ to $32.32 ; \mathrm{p}<0.001)$, education $\geq$ Senior high school (OR= 7.32; 95\% CI $=3.37$ to $32.32 ; \mathrm{p}<0.001)$, community health personnel work at home $(\mathrm{OR}=6.10 ; 95 \% \mathrm{CI}=$ 2.93 to $12.69 ; \mathrm{p}<0.001)$, family income $\geq \mathrm{Rp}$ $1,200,000(\mathrm{OR}=32.30 ; 95 \% \mathrm{CI}=12.91$ to 80.83; p <0.001), tenure $\geq 3$ years $(\mathrm{OR}=$ 16.93; $95 \% \mathrm{CI}=7.75$ to $36.95 ; \mathrm{p}<0.001)$, good skilled $(\mathrm{OR}=16.30 ; 95 \% \mathrm{CI}=7.37$ to 36.08; $\mathrm{p}<0.001$ ), good working environment $(\mathrm{OR}=18.11 ; 95 \% \mathrm{CI}=8.53$ to $38.44 ; \mathrm{p}$ $<0.001)$.

\section{The result of multivariate analysis}

Table 4 shows the influence of the number of children on community health personnel performance. Community health personnel who have children $<3$ have the possibility to perform well 1.89 units higher than community health personnel who have children $\geq 3$ ( $b=$ 1.89 ; $95 \% \mathrm{CI}=0.51$ to 3.26 ; $\mathrm{p}=0.007$ ).

There was an influence of education on community health personnel performance. Community health personnel who have an education $\geq$ Senior high school have the possibility to perform well by 1.88 units higher than community health personnel who were $<$ Senior high school $(b=1.88$; CI $95 \%=$ 0.31 to $3.44 ; \mathrm{p}=0.019$ ). 
Hidayati et al./ Contextual Effect of Integrated Health Post on the Community

There was an effect of employment on community health personnel performance. Community health personnel who worked at home have the possibility to perform well by
2.15 units higher than community health personnel who work outside the home $(b=$ 2.15; CI 95\%=0.48 to $3.82 ; \mathrm{p}=0.011$ ).

Table 3. Bivariate analysis with chi-square test

\begin{tabular}{|c|c|c|c|c|c|c|c|c|}
\hline \multirow{3}{*}{ Variable Groups } & \multicolumn{4}{|c|}{ Performance } & \multirow{3}{*}{ OR } & \multicolumn{2}{|c|}{ CI 95\% } & \multirow{3}{*}{$\mathbf{p}$} \\
\hline & \multicolumn{2}{|c|}{ Poor } & \multicolumn{2}{|c|}{ Good } & & \multirow{2}{*}{$\begin{array}{l}\text { Lower } \\
\text { Limit }\end{array}$} & \multirow{2}{*}{$\begin{array}{l}\text { Upper } \\
\text { Limit }\end{array}$} & \\
\hline & $\mathbf{n}$ & \% & $\mathbf{n}$ & $\%$ & & & & \\
\hline \multicolumn{9}{|l|}{ Number of children } \\
\hline$\geq 3$ Children & 45 & 70.3 & 19 & 29.7 & $15 \cdot 53$ & 7.48 & 32.32 & $<0.001$ \\
\hline$<3$ Children & 18 & 13.2 & 118 & 86.8 & & & & \\
\hline \multicolumn{9}{|l|}{ Education } \\
\hline$<$ Senior high school & 26 & 68.4 & 12 & 31.6 & $7 \cdot 32$ & $3 \cdot 37$ & 15.91 & $<0.001$ \\
\hline$\geq$ Senior high school & 37 & 22.8 & 125 & 77.2 & & & & \\
\hline \multicolumn{9}{|l|}{ Employment } \\
\hline Working outside home & 27 & 64.3 & 15 & $35 \cdot 7$ & 6.10 & 2.93 & 12.69 & $<0.001$ \\
\hline Working at home & 36 & 22.8 & 122 & 77.2 & & & & \\
\hline \multicolumn{9}{|l|}{ Family income } \\
\hline$<\operatorname{Rp} 1,200,000$ & 40 & 85.1 & 7 & 14.9 & 32.30 & 12.91 & 80.83 & $<0.001$ \\
\hline$\geq \operatorname{Rp} 1,200,000$ & 23 & 15.0 & 130 & 85.0 & & & & \\
\hline \multicolumn{9}{|l|}{ Tenure } \\
\hline$<3$ years & 39 & 76.5 & 12 & 23.5 & 16.93 & 7.75 & 36.95 & $<0.001$ \\
\hline$\geq 3$ years & 24 & 16.1 & 125 & 83.9 & & & & \\
\hline \multicolumn{9}{|l|}{ Skills } \\
\hline Poor & 37 & 77.1 & 11 & 22.9 & 16.30 & $7 \cdot 37$ & 36.08 & $<0.001$ \\
\hline Good & 26 & 17.1 & 126 & 82.9 & & & & \\
\hline \multicolumn{9}{|l|}{ Work environment } \\
\hline Poor & 50 & 67.6 & 24 & 32.4 & 18.11 & 8.53 & 38.44 & $<0.001$ \\
\hline Good & 13 & 10.3 & 113 & 89.7 & & & & \\
\hline
\end{tabular}

There was an effect of family income on community health personnel performance. Community health personnel with income of Rp 1,200,000 and above have the possibility to perform well by 1.86 units higher than community health personnel with an income of less than Rp. 1,200,000 (b=1.86; 95\% CI= 0.19 to $3.54 ; \mathrm{p}=0.029$ ).

There was an influence of working period on community health personnel performance. Community health personnel who have a working period of 3 years or more have the possibility to perform well by 2.29 units higher than community health personnel who have a working period of $<3$ years $(b=2.29 ; 95 \% \mathrm{CI}=0.71$ to $3.87 ; \mathrm{p}=0.005)$.

There was an influence of skills on community health personnel performance. Good skilled community health personnel have the possibility to perform well by 2.34 units higher than community health personnel with poor skills $(b=2.34 ; 95 \% \mathrm{CI}=0.53$ to 4.16; $\mathrm{p}=0.011$ ).

There was an effect of the work environment on community health personnel performance. A good work environment of integrated health center (posyandu) was likely to perform well by 1.54 units higher than poor work environment $(b=1.54 ; 95 \% \mathrm{CI}=$ 0.01 to 3.06 ; $\mathrm{p}=0.048$ ). There was a contextual effect of posyandu on community health personnel performance indicated by ICC $=34.98 \%$. This means that $34.98 \%$ of community health personnel performance variations were influenced by variables at the posyandu level. 
Hidayati et al./ Contextual Effect of Integrated Health Post on the Community

Table 4. Multilevel multiple logistic regression on the determinants of community health center performance

\begin{tabular}{|c|c|c|c|c|}
\hline \multirow{2}{*}{ Independent Variables } & \multirow{2}{*}{ b } & \multicolumn{2}{|c|}{$95 \%$ CI } & \multirow[b]{2}{*}{$\mathbf{p}$} \\
\hline & & Lower Limit & Upper Limit & \\
\hline \multicolumn{5}{|l|}{ Fixed Effect } \\
\hline Number of children ( $<3$ children) & 1.89 & 0.51 & 3.26 & 0.007 \\
\hline Education ( $\geq$ Senior high school) & 1.88 & 0.31 & 3.44 & 0.019 \\
\hline Employment (Working at home) & 2.15 & 0.48 & 3.82 & 0.011 \\
\hline Family income ( $\geq \operatorname{Rp} 1,200,000)$ & 1.86 & 0.19 & 3.54 & 0.029 \\
\hline Tenure $(\geq 3$ years $)$ & 2.29 & 0.71 & 3.87 & 0.005 \\
\hline Skill (Good) & 2.34 & 0.53 & 4.16 & 0.011 \\
\hline Work environment (Good) & 1.54 & 0.01 & 3.06 & 0.048 \\
\hline \multicolumn{5}{|l|}{ Random Effect } \\
\hline \multicolumn{5}{|l|}{ Integrated health post } \\
\hline Var (Constants) & 1.77 & 0.37 & 8.52 & \\
\hline \multicolumn{5}{|l|}{ N Observation $=200$} \\
\hline \multicolumn{5}{|l|}{$\mathrm{N}$ Group $=25$} \\
\hline $\mathrm{p}<0.001$ & & & & \\
\hline $\mathrm{ICC}=34.98 \%$ & & & & \\
\hline
\end{tabular}

DISCUSSION

1. The effect of number of children on community health personnel performance

There was an influence on the number of children on performance. Community health personnel who have less than 3 children have the possibility of performing better than community health personnel who have 3 children or more.

This result was in accordance with study done by Ardiani (2018) which stated that the number of children in a family would increase the amount of responsibility and increase the time needed to care for children. This resulted in mothers having less time to have the opportunity to learn and participate in posyandu activities so as to reduce performance.

The lack of time can reduce the level of awareness and responsibility to participate in social activities, in this case the social activeties in posyandu services (Profita, 2018).

2. The effect of education on community health personnel performance There was an effect of education on community health personnel performance. Commu- nity health personnel with high education were more likely to perform better than community health personnel with low educated ones (below HS).

This was in accordance with study done by Chung et al., (2017) which stated that education has an effect on community health personnel performance. Education would have a positive influence in carrying out community health personnel tasks so as to improve performance. The level of community health personnel education can influence knowledge and skills in carrying out community health personnel tasks.

According to Taek et al. (2018), High community health personnel's education can improve community health personnel's performance in health services. Community health personnel were highly educated, easy to understand material about the service and can share the material with others.

3. The effect of employment on community health personnel performance There was an effect of work on the performance of community health personnels. Community health personnel who work at home were more likely to perform better than 
community health personnel who work outside the home.

This study was supported by Ardiani (2018) who stated that work is one of the obstacles of community health personnel in participating posyandu activities. Work that can be done at home such as house wives would have more free time compared to work that must be done outside the home or in a certain place.

The lack of time availability can reduce the level of awareness and responsibility for social activities, which in this case was posyandu services (Profita, 2018).

\section{The effect of family income on com- munity health personnel performance} There was an influence of family income on the performance of community health personnels. A family income of community health personnel of Rp 1,200,000 and above was likely to perform better than community health personnel with a family income of less than $\operatorname{Rp} 1,200,000$.

This was supported by Suhat and Hasanah (2014) stating that community health personnel in Indonesia worked on a voluntary basis so that there was no guarantee of the activeness of community health personnel in participating posyandu activities.

Family income that was not sufficient to fulfill the needs of life can affect the decline in motivation to become community health personnel, in addition to fulfill the family needs, the community health personnel would seek additional income by working. Community health personnel who work have an impact on the reduced availability of time. The less time availability can reduce the level of awareness and responsibility for social activities (Ardiani, 2018; Profita, 2018).

\section{The effect of tenure on community health personnel performance}

There was an influence of the working period on the community health personnel's perfor- mance. The working period of 3 years and above has the possibility of performing better than the community health personnel with working period of less than 3 years.

This was supported by Yuliani et al. (2019) which stated that there was a significant effect of working period on the performance of community health personnel. Increased work periods were in line with the increase in knowledge and skills in posyandu services.

Community health personnel with long working period can improve performance because: they got more training opportunities so that their knowledge was broader, they knew the characteristics of the community, have strong and close relationships with the community, got high trust from the community in their development. The service life can affect the performance, quality, and service satisfaction. In line with the working period of community health personnel through supervision from various sectors so as to improve performance (Alam and Oliveras, 2014).

\section{The effect of skill on community health personnel performance}

The analysis showed that there was an effect of skills on the performance of community health personnel. Good skilled community health personnel were more likely to perform well than community health personnel with lack of skill.

This was in line with study of Hastuti (2018) which stated that community health personnel skills have a significant influence on the performance of health community health personnels. In addition, motivation, job satisfaction, and commitment can affect performance.

According to Kok et al. (2014) in Mpembeni et al. (2015), the existence of financial incentives and nonfinancial incentives (score assessment skills, recognition, development of individual skills or training, leadership, 
supervision, work achievement, peer support and work environment) can increase motivation, job satisfaction, and community health personnel performance.

Supervision to improve the skills of community health personnel can be done by: Increasing awareness of community health personnel tasks, supervising the work of community health personnel in accordance with the task, and knowing the opinion of the community about the role of community health personnel in health services, knowing the suitability of the field with the results of community health personnel documentation and reporting. With supervision, community health personnel would increase their motivation to improve skills: practice, problem solving, and documenttation of posyandu activities (Roberton et al., 2015).

\section{The effect of work environment on community health personnel's perfor- mance}

The analysis showed that there was an effect of the work environment on community health personnel performance. A good work environment has the possibility of community health personnel performing better than poor work environment.

This was in accordance with the study of Lengkong et al. (2019) which showed that work environment skills and work experience can improve performance. In addition, work environment was associated with the level of satisfaction of workers with their work.

A work environment that can provide comfort for community health personnel while on duty and was supported by the availability of facilities that can support posyandu activities. In addition, the nonphysical environment of some elements in the community can affect the motivation of community health personnel in carrying out their duties, so as to improve performance (Kusumawardani and Muljono, 2018).
This was explained by Bazant et al (2014) who stated that the work environment related to the existence of components: commodity interventions in consistent work, skills that support each other and improve service, good feedback between users and service providers, and the existence of a good supervisory function.

This was in accordance with Grant et al. (2018) in Bihar India with the aim of improving the work environment, motivation and performance of community health personnel. The results of the study include: There was good collaboration between community health personnel, there was structural teamwork and team recognition, there was a common perception of the role of supervision by community health personnels, the relationship of trust between community health personnel and good supervisors, and mutual support in community health personnel activities can improve performance.

According to Naimoli et al. (2015), supervision can be done collaboratively by considering: Leaders were close to the activities carried out, people who have skills to foster, and solve problems when activities were carried out.

\section{The contextual effect of Posyandu on community health personnel's per- formance}

The results of multilevel multiple logistic regression analysis showed the contextual effect of posyandu places and community health personnel performance. $34.98 \%$ of community health personnel performance variation was influenced by variables located at the posyandu level.

Integrated health center (Posyandu) is a health facility with community resources focused on mother, baby and infant services. Physical resources were one of the factors that affect performance. The availability of supporting infrastructure for posyandu services was the main thing that affected the 
Hidayati et al./ Contextual Effect of Integrated Health Post on the Community

community health personnel work (Mosadeghrad, 2012; Kusumawardani and Muljono, 2018).

From the study, it was found that there were posyandu infrastructure facilities such as: there was no height measurement tool, educational play equipment, and the implementation of posyandu that used residents' houses. This was found because the village had not yet allocated and optimized the budget for $10 \%$ of UKBM activities from the Village Fund Allocation (ADD) (Ministry of Health, 2015).

Posyandu strata were assessed based on criteria: The number of posyandu activities in a year, the number of community health personnel, the scope of posyandu main activities, the number of additional activities, the availability of community funding sources, and the coverage of participants in the posyandu area (Ministry of Health, 2012). Based on these criteria, it showed that each posyandu has different activities or community health personnel work targets. This was in accordance with study of Kuule et al. (2017) which showed that work assignments and scope of work affect community health personnel performance.

This is in line with Kawakatsu et al. (2015), this study examined the effect of health post levels on performance. The study involved levels of health posts in Kenya consisting of 3 levels: low, medium and high. The results of the study found that the context of the health post by $48 \%$ on the performance of community community health personnel in providing health services.

\section{AUTHOR CONTRIBUTION}

Ulfah Hidayati as the main author has roles to collect related articles, conduct study, analyze data, and wrote scripts. Didik Gunawan Tamtomo gave material advice and discussion about community health personnel performance. Bhisma Murti conducted data analysis and interpretation of data analysis results.

\section{CONFLICT OF INTEREST}

There were no conflicts and interests.

\section{FUNDING AND SPONSORSHIP}

There are no outside funds. The research costs are entirely from the main researcher.

\section{ACKNOWLEDGEMENT}

The authors would like to thank the health office Purworejo Regency for giving permission and Posyandu community health personnel who were willing to participate in the study.

\section{REFERENCE}

Alam K, Oliveras E (2014). Retention of female volunteer community health workers in Dhaka urban slums: A prospective cohort study. Hum Resources Health, 12(29): 1-11. https://doi.org/10.1186/147844911229

Andriani H, Liao CY, Kuo HW (2016). Association of maternal and child health center (Posyandu) availability with child weight status in Indonesia: A national study. Int J Environ Res Public Health, 13(3): 1-10. https://doi.org/10.3390/ijerph13030293

Ardiani N (2018). Relationship between community health personnels' knowledge and motivation and participation in Posyandu community health personnel training at the Jatisrono I Community Health Center in Wonogiri District. Thesis: Universitas Muhammadiyah Surakarta. Retrieved from http://eprints.ums.ac.id/59777/

Bappenas (2015). Report on developments in the achievement of Indonesia's millennium development goals. Jakarta: Bappenas. Retrieved from https://www.bappenas.go.id/files/1913/5229/96- 
Hidayati et al./ Contextual Effect of Integrated Health Post on the Community

28/laporanpencapaiantujuanpembangunanmileniumdiindonesia011_20130517105523_3790_o.pdf

Bazant E, Sarkar S, Banda J, Kanjipite W, Reinhardt S, Shasulwe H, Kim YM, et al. (2014). Effects of a performance and quality improvement intervention on the work environment in HIV related care: A quasi-experimental evaluation in Zambia. Hum Resour Health, 12(1): 1-11. https://doi.org/10.1186/147844911273

Bidayati U (2017). Commitment, motivation, and performance of posyandu community health personnel. ICOI, 13(1): 93-97. https://doi.org/10.2991/icoi17.2017 .27

Chung MHL, Hazmi H, Cheah WL (2017). Role performance of community health volunteers and its associated factors in Kuching District, Sarawak. Int J Environ Res Public Health, 1(1): 1-9. https://doi.org/10.1155/2017/9610928

Dinkes Jateng (2018). Health profile of Central Java Province in 2018. Semarang: Dinas kesehatan Jateng. Retrieved from http://dinkesjatengprov.go.id/v2018/dokumen/profil_2018/mobile/index.html

Grant C, Nawal D, Guntur SM, Kumar M, Chaudhuri I, Galavotti C, Jiwani S, et al. (2018). We pledge to improve the health of our entire community': Improving health worker motivation and performance in Bihar, India through teamwork, recognition, and nonfinancial incentives. PLOS ONE, 13(8): 1-19. https://doi.org/10.1371/journal.pone.0203265

Hastuti D (2018). The influence of motivation, competence, and satisfaction on the performance of health community health personnel with work commitment as an intervening variable (study of the Pagiyanten Health Center in Te- gal Regency). Magisma, 6(1): 23-34. Https://doi.org/10.35829/magisma.v$6 \mathrm{i} 1.16$

Kawakatsu Y, Sugishita T, Tsutsui J, Oruenjo K, Wakhule S, Kibosia K, Honda S, et al. (2015). Individual and contextual factors associated with community health workers' performance in Nyanza Province, Kenya: A multilevel analysis. BMC Health Serv Res, 15(442): 1-10. https://doi.org/10.1186/s1291301511174

Khoirunisa E, Karsidi R, Yusuf M (2019). The role of posyandu as primary health care services in implementing early detection and intervention for autistic children in Indonesia. IJMMU, 6(1): 101109. https://doi.org/10.18415/ijmmu.v6i1.511

Kok MC, Broerse JEW, Theobald S, Ormel H, Dieleman M, Taegtmeyer M (2017). Performance of community health workers: Situating their intermediary position within complex adaptive health systems. Hum Resour Health, 1(1): 1-7. https://doi.org/10.1186/s1296001702$34 \mathrm{z}$

Kusumawardani AS, Muljono P (2018). The relationship between work attitude and motivation with posyandu community health personnel performance: Coper Village and Kutuwetan Village, Jetis District, Ponorogo Regency. JSKPM, 2(2): 223-238. https://doi.org/10.29244/jskpm.2.2.223238

Kuule Y, Dobson AE, Woldeyohannes D, Zolfo M, Najjemba R, Edwin BMR, Wilkinson E, et al. (2017). Community Health Volunteers in Primary Healthcare in Rural Uganda: Factors Influencing Performance. Public Health Front, 5(3): 1-8. https://doi.org/10.3389/fpubh.2017.00062

Lengkong F, Lengkong V, Taroreh R (2019). Effect of skills, experience and work 
Hidayati et al./ Contextual Effect of Integrated Health Post on the Community

environment on employee performance at PT Tri Mustika Cocominaesa (South Minahasa). EMBA, 7(1): 281-290. Retrieved from https://ejournal.unsrat.ac.id/index.php/emba/article/view/22361

Ministry PPPA, BPS (2018). Profile of Indonesian children in 2018. Jakarta: Kementerian Pemberdayaan Perempuan dan Perlindungan Anak dan Badan Pusat Statistik. Retrieved from https://www.kemenpppa.go.id/lib/uploads/list/74d38bukupai2018.pdf

Ministry of Health (2012). Posyandu community health personnel training curriculum and modules. Jakarta: Ministry of Health RI. Retrieved from http://promkes.kemkes.go.id/pub/files/files43996Kurmod_Kader_Posyandu.pdf. Ministry of Health (2015). The Indonesian Ministry of Health's strategic plan for 20152019. Jakarta: Ministry of Health RI. Retrieved from http://www.ppid.depkes.go.id/uploads/img_5cdo7f7e6do39.pdf

Ministry of Health (2019). Indonesia health profile data and information of 2018. Jakarta: Ministry of Health RI. Retrived from https://www.kemkes.go.id/resources/download/pusdatin/profilkesehatanindonesia/DatadanInformasi_ProfilKesehatanIndonesia2018.pdf

Mosadeghrad A (2012). A conceptual framework for quality of care. Mat Soc Med, 24(4): 251-261. https://doi.org/10.5455/msm.2012.24.251261

Mpembeni RNM, Bhatnagar A, LeFevre A, Chitama D, Urassa DP, Kilewo C, George A, et al. (2015). Motivation and satisfaction among community health workers in Morogoro Region, Tanzania: Nuanced needs and varied ambitions. Hum Resour Health, 13(1): 1-10. https://doi.org/10.1186/s1296001500351
Naimoli JF, Perry HB, Townsend JW, Frymus DE, McCaffery JA (2015). Strategic partnering to improve community health worker programming and performance: Features of a communityhealth system integrated approach. Hum Resour Health, 13(1): 1-13. https://doi.org/10.1186/s1296001500413

PBB (2015). Transforming our world: the 2030 Agenda for Sustainable Development. United Nations Sustainable knowledge platform. Retrieved from https://sustainabledevelopment.un.o$\mathrm{rg} /$ post2015/transformingourworld

Profita AC (2018). Several factors related to the activeness of posyandu community health personnel in the Pengadegan Village, Banyumas Regency. JAKI, 6(2): 68-74. Https://doi.org/10.20473/jaki.v6i2.2018.6874

Roberton T, Applegate J, Lefevre AE, Mosha I, Cooper CM, Silverman M, George AS, et al. (2015). Initial experiences and innovations in supervising community health workers for maternal, newborn, and child health in Morogoro region, Tanzania. Hum Resour Health, 13(1): 1-12. https://doi.org/10.1186/s129600150010x

Suhat, Hasanah R (2014). Factors related to activeness of community health personnel in posyandu activities. Kemas, 10(1): 73-79. Retrieved from https://journal.unnes.ac.id/nju/index.php/kemas/article/view/3072

Taek JD, Tnomel K, Oeleu S (2018). Effect performance of posyandu toddlers' community health personnel against satisfaction level mother of infants at Posyandu Melati 9 Health Center Liliba Kota Kupang. JNP, 1(2): 33-40. https://doi.org/10.30994/jnp.v1i2.31.

Tristanti I, Risnawati I (2017). Community health personnel motivation and completeness of card filling towards healthy 
Hidayati et al./ Contextual Effect of Integrated Health Post on the Community

infants in Kudus Regency. Indonesia Jurnal Kebidanan, 1(1): 1-11. Retrieved from https://ejr.stikesmuhkudus.ac.id/index.php/ijb/article/view/221/172

Yuliani I, Murti B, Sulaeman ES, Oepomo TD (2019). Path analysis on the deterninants of health community health personnel ability in early detection and management of pregnancy risk factors in Sleman, Yogyakarta, Indonesia. J Health Policy Manage, 4(1): 47-58. Https://doi.org/10.26911/thejhpm.2019.04.01.06. 